business manuals, government documents, and other contemporary materials. When the constitution and administration of business have been studied from such records, as the constitution and administration of governments have been studied by political historians, we shall have a clearer conception of the development of our business system. It is interesting to speculate on what Miss Beard's book would have been like if she had written from a wealth of historical studies drawn from such sources.

Henrietta M. Larson

\title{
The Brighton Market Bank
}

The Business Historical Society has recently received from the First National Bank of Boston several volumes of records of the Brighton Market Bank, later the National Market Bank of Brighton. The gift includes several books recording names of stockholders and transfers of stock, a book giving the minutes of stockholders' meetings, and a volume of directors' minutes. The directors' minute book begins with 1854 and ends in 1891 .

The directors' minute book tells a very important story. It is to be regretted that the set of books includes no ledgers, for without them no detailed, and hence satisfactory, study can be made of the Brighton Bank. But something of the history of the Bank that is important can be gained from the minute book. Some statistics gleaned from the volume and a few facts chosen here and there on the history of this early Brighton bank will illustrate the nature of the material contained in the directors' records.

First, just a few words about the Bank and the conditions under which it was to work. The Brighton Bank was clearly organized to serve the livestock market in Brighton, now a part of Boston. Brighton was then the stockyard and packing center of the Boston area; it was the training school of Gustavus Swift, who founded the great Chicago meat-packing firm which bears his name. The Bank was established in the 1850's when there was no national regulation of banking and no national system of banking or national bank currency. The years covered by this volume brought great developments and great problems in American business: the Brighton Market Bank was floated in the boom following the depression of 1854 and preceding the panic of 1857, and the decades which followed, down to 1891, brought war, expansion, and long periods of depression, while the meat-packing industry experienced a shift 
in production to the Middle West which must have had serious consequences to the industry in Brighton.

Something of the process of setting up a bank almost a hundred years ago is recorded by the directors' minute book. Just before the panic of the summer of 1854, a corporation was formed under Massachusetts law to establish the Brighton Market Bank with a capital of $\$ 100,000$. In the summer of 1854 the directors purchased a site for the Bank, had a building erected, purchased furniture and record books, and provided for the engraving of bank notes. They also selected three salaried officers for the Bank: the president, cashier, and assistant or messenger-there was considerable disagreement over salaries, but it was finally decided to pay the president $\$ 1,300$ and the cashier $\$ 900$ a year. On August 1 the directors voted to require full payment of shares by September 18, any shares then unpaid to revert to the corporation. It is significant that on September 4 , when the money market throughout the country was exceedingly tight, the directors voted to propose an increase in the capital of the corporation.

The minutes do not record on what day the Bank was actually opened for business, but September 19 clearly marked the completion of the preliminaries. "At 8 o'clock a.m.", says the record, "the Commissioners appointed by the Governor to count and examine the Specie paid in, as the Capital Stock of the Bank, appeared and attended to that duty." Eight directors and the president of the board were present and "made the customary oath." A directors' meeting was held in the afternoon. Three o'clock on Thursday of each week was voted as the regular time for the directors to act on discounts, with the provision that when he should "deem it for the interest of the Bank, the President, with such Directors as he may be able to consult, be authorized to discount paper between the regular discount days." One director was requested "to procure some person to sleep in the Bank." The cashier was at this meeting properly installed by taking an oath. ${ }^{1}$

The most valuable material in the directors' minute book is the semi-annual reports on the condition of the Bank. Those reports record for a given date, usually in March and September, the capi-

${ }^{1}$ I, K. E. Graves, do solemnly swear that I will perform faithfully and diligently, and to the best of my ability, the duties now assigned or which may be assigned to me as Cashier of the Brighton Market Bank, and that I will not impart any knowledge affecting the interests of said Bank except to those persons who have the direction thereof, unless required in a Court of Justice. So help me God. 
tal and surplus, the state of the profit and loss account, circulation, deposits, discounts, specie, holdings of government and other securities, and so on. Operating results are given for the six months' period in the form of gross income from which are deducted expense and other items, leaving net earnings. At this time are also recorded losses on unpaid notes and action on mortgages. Finally, the dividend is voted.

The following table has been compiled to show the earnings and the disposal of the earnings of the Bank over the years 18551891 included in the directors' minute book:

\section{SOME FIGURES FROM THE STATEMENTS \\ OF THE BRIGHTON NATIONAL BANK MARCH AND SEPTEMBER, 1855-1891}

Balance in

\begin{tabular}{|c|c|c|c|c|c|}
\hline \multirow{3}{*}{$\begin{array}{l}\text { Year } \\
1855\end{array}$} & \multirow{3}{*}{$\begin{array}{r}\text { Capital } \\
\$ 100,000\end{array}$} & \multicolumn{2}{|r|}{ Profit and Loss } & \multicolumn{2}{|r|}{ Dividends } \\
\hline & & Surplus & Account & Net Earnings & in Per Cent \\
\hline & & & $\$ 1,150.47$ & $\$ 3,768.93^{a}$ & 4 \\
\hline & 200,000 & & $1,759.92$ & $7,246.68$ & 4 \\
\hline \multirow[t]{2}{*}{1856} & 200,000 & & $5,883.87$ & $11,650.48$ & $41 / 2$ \\
\hline & 200,000 & & $7,246.49$ & $17,048.66$ & 5 \\
\hline \multirow[t]{2}{*}{1857} & 200,000 & & $8,451.67$ & $11,118.95$ & 5 \\
\hline & 250,000 & & $9,149.24$ & $12,270.17$ & $4 \frac{1}{2}$ \\
\hline \multirow[t]{2}{*}{1858} & 250,000 & & $9,474.06$ & $11,011.07$ & 4 \\
\hline & 250,000 & & $11,294.20$ & $10,029.24$ & $4 \frac{1}{2}$ \\
\hline \multirow[t]{2}{*}{1859} & 250,000 & & $11,109.09$ & $12,286.50$ & $41 / 2$ \\
\hline & 250,000 & & $11,971.89$ & $11,504.73$ & $4 \frac{1}{2}$ \\
\hline \multirow[t]{2}{*}{1860} & 250,000 & & $10,901.59$ & $12,244.98$ & $41 / 2$ \\
\hline & 250,000 & & $11,554.16$ & $11,400.68$ & $41 / 2$ \\
\hline \multirow[t]{2}{*}{1861} & 250,000 & & $11,762.42$ & $10,328.82$ & 4 \\
\hline & 250,000 & & $9,049.92$ & $6,088.25$ & 3 \\
\hline \multirow[t]{2}{*}{1862} & 250,000 & & $11,302.42$ & $9,493.88$ & 3 \\
\hline & 250,000 & & $10,525.83$ & $9,705.81$ & 3 \\
\hline \multirow[t]{2}{*}{1863} & 250,000 & & $7,476.38$ & $13,080.78$ & 3 \\
\hline & 250,000 & & $9,618.24$ & $12,098.97$ & 3 \\
\hline \multirow[t]{2}{*}{1864} & 250,000 & & $10,001.92$ & $13,005.04$ & 4 \\
\hline & 250,000 & & $15,753.04$ & $12,776.40$ & $41 / 2$ \\
\hline \multirow[t]{2}{*}{1865} & 250,000 & & $26,442.77$ & $28,929.68^{b}$ & 10 \\
\hline & 250,000 & 3,000 & $14,954.00$ & $16,790.29 b$ & 5 \\
\hline \multirow[t]{2}{*}{1866} & 250,000 & 5,000 & $14,596.19$ & $19,520.98$ & 5 \\
\hline & 250,000 & 7,500 & $18,527.50$ & $19,416.47$ & 5 \\
\hline \multirow[t]{2}{*}{1867} & 250,000 & 10,000 & $22,045.62$ & $21,132.11$ & 5 \\
\hline & 250,000 & 20,000 & $23,937.17$ & 21.175 .70 & 5 \\
\hline \multirow[t]{2}{*}{1868} & 250,000 & 30,000 & $21,611.80$ & $21,003.23$ & 5 \\
\hline & 250,000 & 40,000 & $23,175.88$ & $21,403.45$ & 6 \\
\hline \multirow[t]{2}{*}{1869} & 250,000 & 50,000 & $17,569.76$ & $22,727.22$ & 6 \\
\hline & 250,000 & 50,000 & $27,081.87$ & $22,934.90$ & 6 \\
\hline \multirow[t]{2}{*}{1870} & 250,000 & 50,000 & $32,579.84$ & $19,802.55$ & 6 \\
\hline & 250,000 & 50,000 & $37,179.61$ & $18,850.35$ & 6 \\
\hline
\end{tabular}




\begin{tabular}{|c|c|c|c|c|c|}
\hline \multirow{4}{*}{$\begin{array}{l}\text { Year } \\
1871\end{array}$} & & & $\begin{array}{c}\text { Balance in } \\
\text { Profit and Loss }\end{array}$ & & Dividends \\
\hline & Capital & Surplus & Account & Net Earnings & in Per Cent \\
\hline & 250,000 & 50,000 & $41,819.30$ & $20,693.34$ & 6 \\
\hline & 250,000 & 75,000 & $24,434.19$ & $21,875.97$ & 6 \\
\hline \multirow[t]{2}{*}{1872} & 250,000 & 75,000 & $30,341.45$ & $24,023.06$ & 6 \\
\hline & 250,000 & 75,000 & $40,404.83$ & $24,220.20$ & 7 \\
\hline \multirow[t]{2}{*}{1873} & 250,000 & 100,000 & $21,896.32$ & $25,425.38$ & 7 \\
\hline & 250,000 & 100,000 & $30,404.60$ & $24,931.65$ & 7 \\
\hline \multirow[t]{2}{*}{1874} & 250,000 & 100,000 & $33,476.77$ & $24,122.72$ & 7 \\
\hline & 250,000 & 100,000 & $40,700.29$ & $24,884.62$ & 7 \\
\hline \multirow[t]{2}{*}{1875} & 250,000 & 100,000 & $43,561.06$ & $23,186.48$ & 7 \\
\hline & 250,000 & 100,000 & $50,782.98$ & $26,290.60$ & 7 \\
\hline \multirow[t]{2}{*}{1876} & 250,000 & 100,000 & $53,901.17$ & $22,268.18$ & 6 \\
\hline & 250,000 & 100,000 & $57,947.65$ & $20,328.00$ & 6 \\
\hline \multirow[t]{2}{*}{1877} & 250,000 & 100,000 & $64,399.51$ & $17,589.23$ & 6 \\
\hline & 250,000 & 100,000 & $59,436.13$ & $13,651.21$ & 5 \\
\hline \multirow[t]{2}{*}{1878} & 250,000 & 100,000 & $61,206.79$ & $17,460.94$ & 5 \\
\hline & 250,000 & 100,000 & $64,532.62$ & $12,416.30$ & 5 \\
\hline \multirow[t]{2}{*}{1879} & 250,000 & 100,000 & $49,136.26$ & $15,372.33$ & $41 / 2$ \\
\hline & 250,000 & 100,000 & $50,529.10$ & $16,869.72$ & 4 \\
\hline \multirow[t]{2}{*}{$1880^{c}$} & & & $53,099.36$ & $19,076.35$ & $25^{d}$ \\
\hline & 250,000 & 50,000 & $54,046.54$ & $16,254.05$ & 4 \\
\hline \multirow[t]{2}{*}{1881} & 250,000 & 50,000 & $56,791.69$ & $17,843.23$ & 4 \\
\hline & 250,000 & 50,000 & $63,309.31$ & $18,416.34$ & 4 \\
\hline $1882^{e}$ & 250,000 & 50,000 & $65,525.75$ & $19,954.05$ & 4 \\
\hline \multirow[t]{2}{*}{1883} & 250,000 & 50,000 & $66,510.39$ & $19,262.36$ & 4 \\
\hline & 250,000 & 50,000 & $66,369.22$ & $18,972.12$ & 4 \\
\hline \multirow[t]{2}{*}{1884} & 250,000 & 50,000 & $63,648.43$ & $17,510.17$ & 4 \\
\hline & 250,000 & 50,000 & $62,349.32$ & $14,676.14$ & $31 / 2$ \\
\hline \multirow[t]{2}{*}{1885} & 250,000 & 50,000 & $64,612.00$ & $13,639.81$ & $31 / 2$ \\
\hline & 250,000 & 50,000 & $70,628.55$ & $15,737.90$ & $31 / 2$ \\
\hline $1886^{\circ}$ & 250,000 & 50,000 & $80,341.29$ & $17,338.50$ & $31 / 2$ \\
\hline \multirow[t]{2}{*}{$1887^{c}$} & 250,000 & 50,000 & $87,756.48$ & $18,524.11$ & $31 / 2$ \\
\hline & & & & $17,369.08$ & $31 / 2$ \\
\hline \multirow[t]{2}{*}{1888} & 250,000 & 100,000 & $54,409.73$ & $17,483.17$ & $31 / 2$ \\
\hline & 250,000 & 100,000 & $66,210.26$ & $17,770.72$ & $31 / 2$ \\
\hline \multirow[t]{2}{*}{1889} & 250,000 & 100,000 & $62,274.79$ & $18,059.74$ & $31 / 2$ \\
\hline & 250,000 & 75,000 & $29,541.82$ & $15,867.18$ & 2 \\
\hline \multirow[t]{2}{*}{1890} & 250,000 & 50,000 & $13,076.60$ & $11,319.52$ & 2 \\
\hline & 250,000 & 50,000 & $20,000.05$ & $12,371.83$ & 2 \\
\hline $1891^{\mathrm{c}}$ & 250,000 & 50,000 & $16,458.38$ & & \\
\hline
\end{tabular}

aUntil Sept., 1864, paid but unearned interest was subtracted from earnings. bNo report on net earnings. Figure given is for "balance of profits," from which certain deductions were usually made, as for unearned interest, etc. cFor March, 1880, September, 1887, and March, 1891, reports were incomplete. dincludes regular dividend of $5 \%$ in March and an additional $20 \%$. eNo report was recorded for September, 1882, and March, 1886. 
This table reveals a very interesting record of earnings as well as a notable dividend policy. It would be very useful to the student of banking history to learn something about the men and the policies behind this record. No doubt Life Baldwin, the president of the Brighton Market Bank, was a very able man, but one would like to have known him as an individual, to know what other business experience he had had, and what were his contacts in Brighton. Others among the directors also merit study. To gain satisfactory information about the operation of the Bank it would, also, be necessary to study its ledgers. It is to be hoped that in time they will be added to the collection now in the possession of the Business Historical Society.

A number of questions suggested by the above table can in part be explained from the directors' records. At first glance, the fall in dividends during the early years of the Civil War is astonishing in view of the general profitableness of business at the time, but it is apparently explained by the fact that in those years the Bank wrote off some old notes long overdue. The earnings of the Bank in the panic year of 1873 and the depression years immediately following are surprisingly high. As a matter of fact, the early 1870's brought a very great increase in the discounts and a considerable increase in the deposits of the Bank. In the later 1870's, however, discounts fell, though deposits at times were greatly increased.

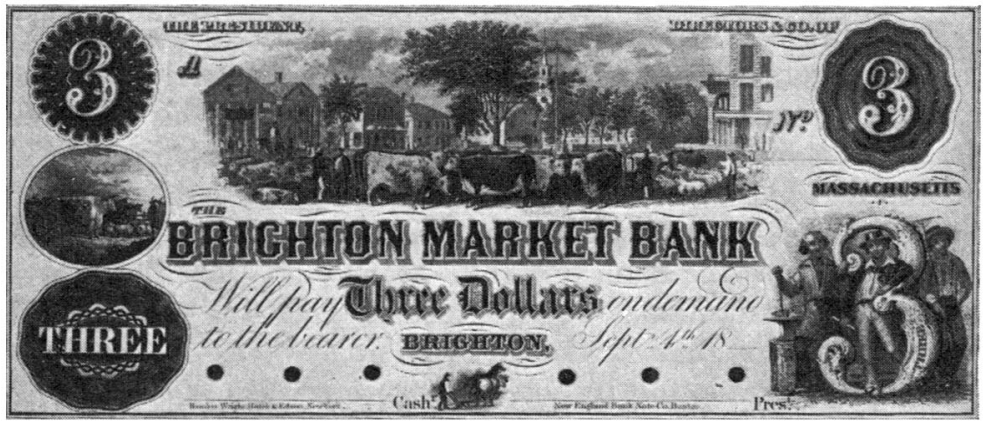

In 1880 the Bank ran into a problem. The Brighton Market was moved to the new freight depot of the Boston \& Albany Railroad some distance away. The directors then recommended the liquidation of the Bank. A stockholders' meeting of March 25 voted that preliminary steps be taken for winding up the affairs of 
the Bank, and provision was made for disposing of real estate or mortgages held. On April 9, however, the stockholders' vote barely saved the Bank. Only a few days later an extra dividend of $20 \%$ was declared, and on April 28 the directors voted to pay the dividend out of surplus. The reports of the meetings give no explanation of the voting of so large a dividend out of surplus, but one wonders if it had any relation to the decision to continue the Bank. On the very day that the dividend was voted out of surplus, the directors started to make arrangements for moving the Bank to a site near the new market-place.

The dividends of the 1880's were low as compared with those of the 1870's. This was in part the result of placing some of the earnings in the profit and loss account for the purpose of restoring the surplus to $\$ 100,000$, which was done in 1888 . At the same time, earnings actually did fall very considerably. The most serious decline came, however, after March, 1889. From March to September of 1889 , discounts fell from $\$ 619,000$ to $\$ 493,000$ and deposits from $\$ 199,000$ to $\$ 138,000$. More serious than the fall in earnings, even, were the losses. In 1889 heavy losses were taken on overdue notes. The most conspicuous of these losses was that which resulted from the sale of three notes, which totaled $\$ 120,000$, presumably as the directors voted, at not less than $45 \%$. The sum of $\$ 25,000$ was charged to surplus and the remainder to profit and loss. Again in January, 1890, bad notes were written off for $\$ 27,000$, for which $\$ 25,000$ was again pared off surplus.

The story ends inconclusively. The last entry on the last page of the directors' minute book, of July 29,1891 , is merely the usual report of a regular weekly meeting of the board: "A list of all the Notes discounted as per offering [was] read and approved by the Board." One wonders how the Bank weathered the bad years to come, and what happened to the Brighton cattle market. Other sources show that the Bank survived. Many years later it was taken over by the International Trust, which in 1923 was merged with the First National Bank of Boston.

\section{IIn Attemariam}

Francis Russell Hart, a member of the Society since 1926, died on January 18 at his home in Boston. He had celebrated his seventieth birthday only two days before. 